\title{
OPTIMIZATION OF ENERGY MANAGEMENT IN A CITY BUS POWERED BY THE HYDROGEN FUEL CELLS
}

\author{
Arkadiusz Malek $^{1, *}$, Rodolfo Taccani ${ }^{2}$, Dariusz Kasperek ${ }^{3}$, Jacek Hunicz ${ }^{4}$ \\ ${ }^{1}$ University of Economics and Innovation, Lublin, Poland \\ ${ }^{2}$ University of Trieste, Trieste, Italy \\ ${ }^{3}$ Ursus Bus, Lublin, Poland \\ ${ }^{4}$ Faculty of Mechanical Engineering, Lublin University of Technology, Lublin, Poland \\ *E-mail of corresponding author: arkadiusz.malek@wsei.lublin.pl
}

\section{Resume}

The article describes the design and optimization of operation of an electric bus powered by the hydrogen fuel cells. At the beginning, an approach to design of a 12-meter urban bus, powered by hydrogen, is presented, as well as examples of components for its construction. Next, the problem of selecting the size of traction batteries and stacks of the Proton Exchange Membrane (PEM) hydrogen fuel cells was discussed. These are the key components affecting the price of the bus and should be subject to optimization. The results of optimization of the size of traction batteries and the fuel cell system for a bus traveling in inter-city traffic are presented. The optimization was based on data from the literature and data from the monitoring system of actual hydrogen powered buses located on the Internet platform. The main purpose of the research, which was to determine the total costs of ownership (TCO), is presented as well.

\section{Article info}

Received 17 September 2020

Accepted 22 March 2021

Online 23 August 2021

\section{Keywords:}

hydrogen,

fuel cell,

fuel cell bus, control strategy, total costs of ownership, energy management

\section{Introduction}

The constant pursuit of improving air quality in cities has given rise to the need for new solutions aimed at reducing $\mathrm{CO}_{2}$ emissions. This includes the urban transport sector [1]. The use of alternative fuels and propulsion systems based on electricity and hydrogen is an important activity in this respect [2]. Alternative fuels, characterized by the low $\mathrm{CO}_{2}$ emissions, are an important factor in the gradual reduction of transport emissions, which is the basic goal of the Europe 2020 strategy. The strategy includes development of sustainable transport for the first half of the 21st century regarding a $60 \%$ reduction in $\mathrm{CO}_{2}$ emissions by 2050 in transport. The use of such fuels will also have a beneficial effect on the ability of urban areas to meet the EU air quality commitments, this includes the elimination of conventional vehicles by 2050 . Both city authorities [3], municipal transport companies and bus manufacturers are involved in pursuing this goal [4]. Buses fleet electrification is possible by production of the new models or conversion existing vehicles [5-6]. It is noteworthy that the zero emissions of electric and electric-hydrogen buses at their place of use is just one of their many advantages. Other benefits include a lack of noise [7], vibrations and a high level of driving dynamics resulting from characteristics of electric motors [8].
For the city and intercity buses, the area of energy management is very wide. Many research works, carried out in the last 10 years, are concerned with the optimal use of energy from several decentralized sources, most of which use renewable energy sources. Hydrogen and fuel cells are seen as an indispensable component of both stationary and mobile electricity generators [9-10]. Very often energy production and its consumption on board vehicles are considered separately. Fuel consumption prediction is very helpful in planning a hydrogen vehicle route [11].

Entire hydrogen-powered fleets are being increasingly implemented in selected European cities. Such investments are long-term investments and, in addition to the vehicles themselves, require the construction of infrastructure for hydrogen production and refuelling [12]. Increasingly, hydrogen to power vehicles comes from the electrolysis of water using electricity from renewable energy sources. Such hydrogen is characterized by very high purity and does not contain any harmful components that can poison hydrogen fuel cells. In the case of long-term investments, the time of correct operation of both hydrogen cells and hydrogen fuel cells is of a great importance [13]. For the latter, the expected working time is from 20,000 to 30,000 hours and the guaranteed time is 15,000 hours. The entire vehicle fleet should be able to be monitored online, which 
allows for preventive maintenance and optimization of all the application functions. Online and offline analyses allow to calculate the actual costs of using vehicles. They can be used to calculate the payback time and to compare the costs of different solutions to each other.

When it comes to energy management on board vehicles, it can be seen that it is more convenient to separate the two problems according to the time horizon. In the long term, energy management can be based on criteria depending on forecasts, investment and infrastructure costs, and the size of optimization steps. The real-time energy management is, however, required to achieve optimal power distribution on board the vehicle subject to power restrictions using given powertrain architecture components [14].

In the case of the hybrid bus traction system, the power demand must be met. Full optimization is possible with knowledge of the power flow characteristics and route profile. The total optimum is achieved provided that the energy consumption is minimized over the entire known route [15].

Previous articles explored different approaches to managing energy distribution for the same type of traction chain and increasing autonomy, minimizing fuel consumption by the main power source [16]. Among these approaches, dynamic programming, used offline when the route profile is known, is undoubtedly the most cited in the literature. This method, based on the Bellman principle, based on the discretization of the energy space of the storage system, reveals some weaknesses associated with the choice of the size of the discretization step, which significantly affects the time of calculations and the quality of decisions. Another method often cited in this area is the Optimal Control approach based on the Pontryagin minimum principle and calculation of derivatives of the Hamilton function or reporting of consumption of all the sources in an equivalent space in which the optimal control is carried out. Energy management methods on board hydrogen buses are still being developed with using a combinatorial optimisation approach to energy management [17]. Very promising is a real-time optimization [14], hierarchical approximate global optimization [18] and multi-mode prediction of the energy consumption, both in the stationary and mobile applications [19]. Control strategies for fuel saving in the hydrogen fuel cell vehicles should be still developed and promptly applied to existing and new produced vehicles [20-21].

City and intercity buses are usually built in hybrid systems. Most of them are specially designed to achieve the low total costs of ownership for heavy duty applications. The element, contributing to the low total cost of ownership, is selection of the key components with long life and high performance [22]. The power of hydrogen fuel cells and the energy capacity of traction batteries determine not only the production costs of a hydrogen bus, but its performance and operating costs, as well.
The authors propose a comprehensive approach to design of a hydrogen bus taking into account its exact purpose. This approach has used all the latest components on the market for hydrogen bus construction and control techniques. All the stages that take into account the simulation should then be validated under real conditions [23].

\section{Components of the electric and hydrogen city bus}

During the last 10 years, electric drive systems dominated with increasingly larger traction batteries in order to obtain a greater range. This took place both for the drive of passenger vehicles and buses. However, many companies conducted parallel research and development related to use of hydrogen as fuel. Stacks of fuel cells and hydrogen tanks capable of powering city buses have been developed. Hydrogen technologies have the special advantage of faster hydrogen refuelling than charging vehicle traction batteries with fast DC chargers. Development of the hydrogen refuelling infrastructure for vehicles at 350 and 700 bar was also observed. These are favourable conditions for dissemination of the hydrogen-using drives in both passenger cars and buses.

In the 21st century, many components became available to build an electric bus drive system. The most important of them include: an electric motor and traction batteries and in the case of hydrogen propulsion, a fuel cell stack and hydrogen tanks. The appropriate selection of each component determines the suitability of the bus for a specific application (urban, intercity) and its price. In addition to the correct selection of components, it is also important to integrate them in order to obtain the trouble-free operation with high efficiency [24].

\subsection{Electric motor and drive axle}

The task of the electric drive system is to efficiently transfer power to the road wheels in all the bus operating conditions [25]. One of the most important components is the electric motor whose parameters determine its suitability for bus propulsion. According to global and European trends, in production of both passenger cars and buses, a Permanent Magnet Synchronous Motor (PMSM) is the most popular choice.

Three drive concepts, central-motor, electric portal axle and in wheel hub drive, fitted in a 12 metre electric bus with a daily mileage of $200 \mathrm{~km}$ based on a usage period of 340 days a year, were compared by a bus manufacturer (see Figure 1). The bus was equipped according to the current standard of the respective manufacturers and the selected driving cycle SORT2. In order to ensure comparability, the tyre pressure and the total/overall vehicle weight (m 14,410 kg) were adjusted accordingly [26]. 


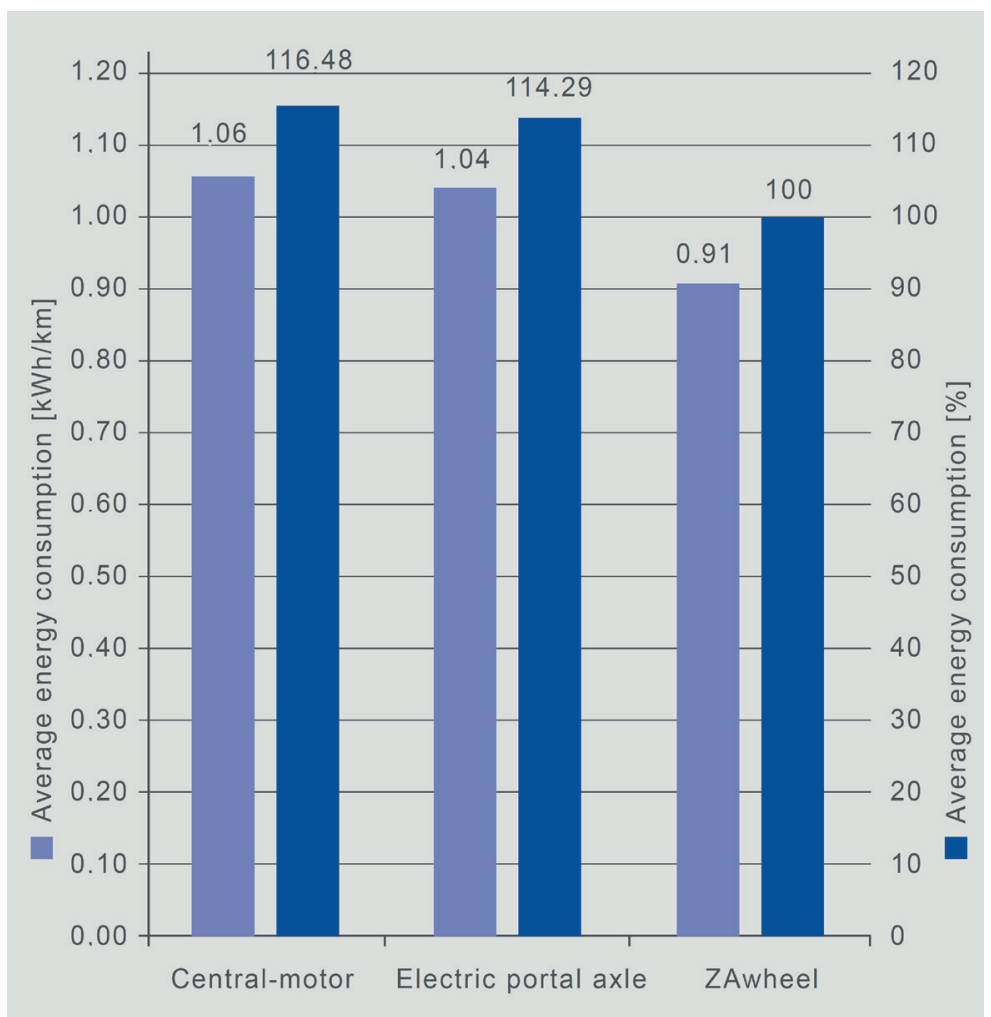

Figure 1 Comparison of different drive concepts [26]

The results were unambiguous. The direct costs benefits of a wheel hub drive include:

- Reduction of initial costs due to smaller battery pack (approx. $30 \mathrm{kWh}$ lower)

- Reduction of annual operational costs due to low energy consumption (approx. 8,840 - 10,200 kWh less)

Further benefits of the wheel hub drive:

- Minimal installation space requirements

- Weight reduction

- Low maintenance

- Minimal noise characteristics $(<70 \mathrm{dBA}$ at $80 \mathrm{~km} / \mathrm{h})$

\subsection{Traction battery}

Traction batteries are another key component of the electric bus drive system. The most common technology used in the automotive industry is lithium-ion batteries, which are available in many varieties [27]. According to the authors, the NMC-type lithium-ion batteries (lithium nickel manganese cobalt oxide battery - LiNiMnCoO2 or NMC) should be used to build a low-costs, but highly reliable energy storage system. Lithium-titanium (LTO) batteries are increasingly used in the construction of electric buses [28]. They are characterized by a tolerance to very high currents during the charging process, which significantly reduces the charging time. Supercapacitors are used for the short-term storage of electrical energy recovered during the braking [29]. However, due to their high price and limited use, they have not been fitted in many road vehicles as yet [30]. The charging process of the batteries should be included in any discussion about traction batteries. The optimal solution, due to infrastructure costs and the time required to fully charge the battery, is charging with direct current using external chargers. The CCS Combo 2 charging system can charge with up to $150 \mathrm{~kW}$ of power. It is worthwhile for every electric bus to have an on-board charger with a power output of at least $20 \mathrm{~kW}$, which may be supplied from a three-phase $400 \mathrm{~V}$ socket. The expansion of the charging infrastructure should be developed along with an increase in the number of electric buses [31].

\subsection{Fuel cell system}

The type of fuel cell that best meets contemporary automotive requirements is the PEM (Proton Exchange Membrane) cell. This assertion has been confirmed by the trends among leaders in this field. The PEM fuel cells have been used to build many working prototypes and commercial vehicles.

The choice of the LTPEM (Low Temperature Proton Exchange Membrane) or High Temperature HTPEM (High Temperature Proton Exchange Membrane) system has a significant impact on the control strategies used for the entire power generation system under various operating conditions and this translates into some challenges related to their operation. The LTPEM functions normally at temperatures of up to $85{ }^{\circ} \mathrm{C}$ while the HTPEM operates normally up to $200{ }^{\circ} \mathrm{C}$. 
Table 1 Comparison of parameters of different hydrogen buses

\begin{tabular}{|c|c|c|c|c|c|}
\hline $\begin{array}{l}\text { bus name or project } \\
\text { title }\end{array}$ & $\begin{array}{l}\text { electric motor type } \\
\text { and power } \\
(\mathrm{kW})\end{array}$ & $\begin{array}{l}\text { battery type and } \\
\text { energy capacity } \\
(\mathrm{kWh})\end{array}$ & $\begin{array}{l}\text { fuel cell system type } \\
\text { and power }(\mathrm{kW})\end{array}$ & $\begin{array}{l}\text { hydrogen tanks } \\
\text { capacity }(\mathrm{kg})\end{array}$ & $\begin{array}{l}\text { additional } \\
\text { systems }\end{array}$ \\
\hline $\begin{array}{c}\text { Ursus bus hydrogen } \\
\text { bus }\end{array}$ & wheel-hub $2 \times 110$ & $2 \times 37.8$ & $2 \times 30$ & 33 & \\
\hline Van Hool CHIC & & 100 & 150 & 35 & break resistors \\
\hline EVO bus CHIC & wheel-hub & 250 & $2 \times 60$ & 35 & \\
\hline Wrightbus & & 0 & 75 & 33 & $\begin{array}{c}\text { break resistors, } \\
\text { supercapacitor } \\
240 \mathrm{~kW}\end{array}$ \\
\hline Solaris Urbino 12 & wheel-hub 2x125 & 120 & 60 & 36.8 & \\
\hline
\end{tabular}

The HTPEM systems, despite several disadvantages, have numerous advantages over the LTPEM systems, as well. The first of these concerns the lack of a need to moisten the membrane and use of a complicated and expensive humidifier. Further advantages with the simple construction of the entire HTPEM system are associated with the greater efficiency of the entire system, which compensates for the $10 \%$ lower voltage performance of the cell itself [32]. Greater CO tolerance by the HTPEM systems translates into the possibility of using hydrogen from steam reforming of hydrocarbon fuels to supply them.

In the case of use of the hydrogen, originating from hydrolysis or reforming characterized by a purity of $99.999 \%$, the cheapest solution would be to use LTPEM type cells.

\subsection{Hydrogen storage}

There are many ways to accumulate hydrogen. It can be collected in a compressed or cryogenic version. The latter method allows for accumulation of large amounts of hydrogen in a small volume. However, this is very expensive due to the need to maintain very low temperatures at the level of production, distribution and transport of hydrogen. There are also hybrid tanks available with cryogenic and additionally compressed hydrogen (cryo-compressed tanks) [33]. Hydrogen can also be collected in metal hydrides. They are very straightforward to use and efficient, but they have one drawback - they are excessively heavy. One of the newest methods of hydrogen accumulation is use of tanks made from carbon nanotubes [34]. However, metal or composite high pressure tanks are most often used to accumulate hydrogen on board vehicles. Several European and global manufacturers produce tanks with international approval.

\section{Overview of solutions in existing projects}

Continuous striving to improve air quality in cities necessitates the search for new solutions aimed at reducing $\mathrm{CO}_{2}$ emissions in the urban transport sector. An important activity in this area is use of alternative fuels and drives. Currently, they include electricity and hydrogen. Polish and European urban bus manufacturers are introducing new generations of eco-friendly city buses [1].

Electric-hydrogen bus projects are most often implemented by consortia of bus manufacturers, universities, research institutes and science and technology parks. It is often the case that specialized start-ups with software and firmware programming skills in the newest programming languages are included in these groups. Table 1 gathers data from several ongoing projects that aim to build an electric-hydrogen bus at the TRL9 standard (Technology Readiness Level).

\section{Research aim - Ursus demo hydrogen bus}

A practical example of a performance design and production costs optimization is the Ursus Demo Hydrogen Bus. The vehicle uses two $30 \mathrm{~kW}$ LTPEM cell modules (total power $60 \mathrm{~kW}$ ), compatible with a set of NMC lithium-ion batteries with an energy capacity of $70 \mathrm{kWh}$. More specifically, it is an electric bus with a hydrogen range extender [35]. This is due to impossibility of the supplying the electric motor directly from the fuel cell system. The motors are powered by traction batteries and the hydrogen system recharges them constantly.

Hydrogen is stored on board in a compressed form under a pressure of $35 \mathrm{MPa}$, which is the European standard in this area. The vehicle range is approximately $450 \mathrm{~km}$ and is expected to increase. The service life assumed by the manufacturer is 20000 working hours, which corresponds to a mileage of $700000 \mathrm{~km}$.

The drive system consists of electric motors located in the wheel hubs, roof-mounted traction batteries and 2 hydrogen fuel cell modules located at the back of the bus, as shown in Figure 2.

The electric bus with a hydrogen range extender has many advantages, which include [36]:

- traction properties exceeding those of typical electric buses - the vehicle's range without charging the 


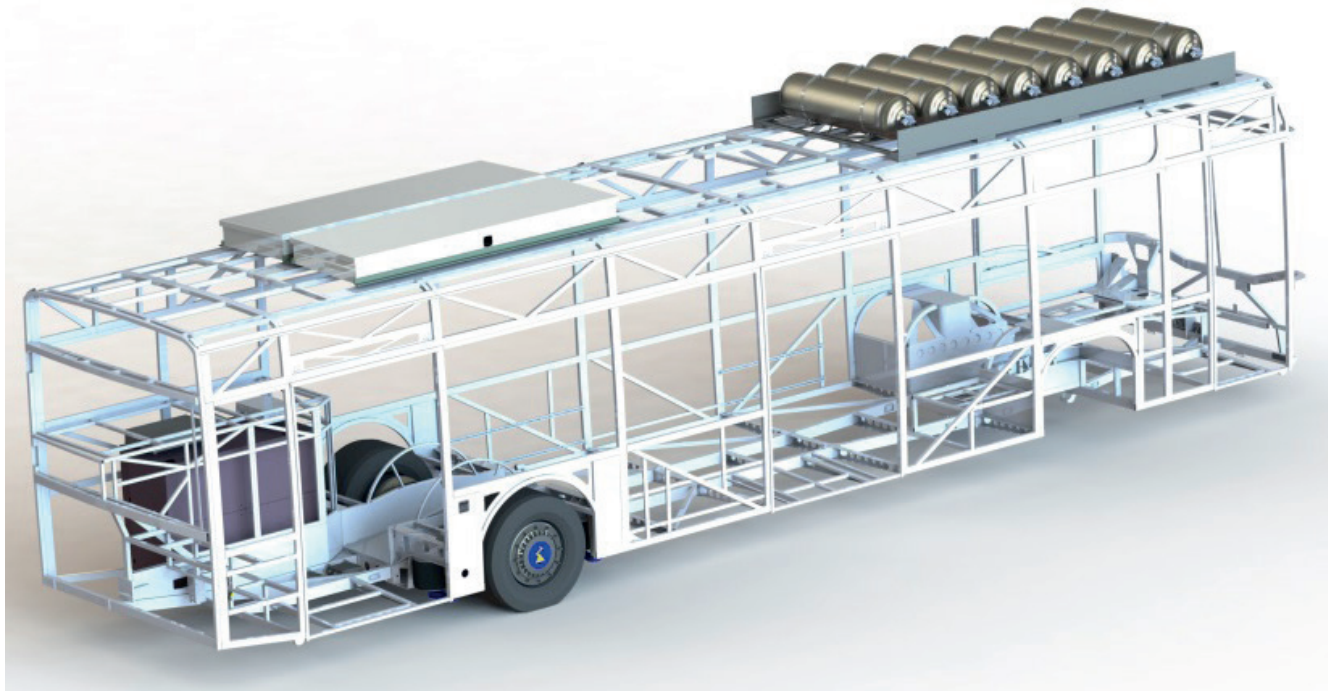

Figure 2 Arrangement of components in the bus

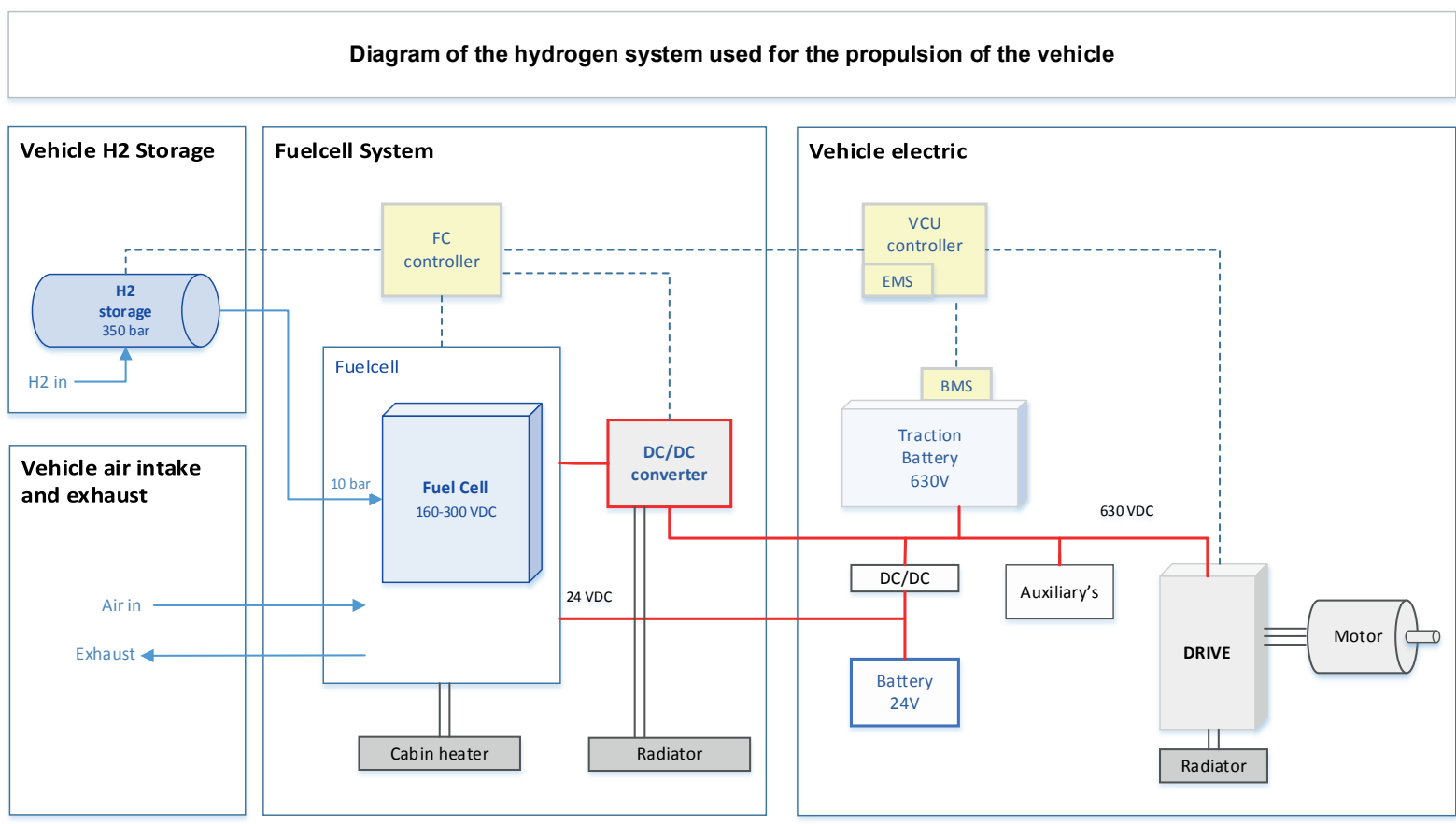

Figure 3 Diagram of the propulsion system of the hydrogen bus

battery is approximately $450 \mathrm{~km}$;

- the option of travelling on intercity communication lines;

- quick refuelling of hydrogen to on-board tanks, the process lasts approximately $15 \mathrm{~min}$;

- high travel comfort - "smooth ride", no noise or vibration.

The Ursus FCEB (Fuel Cell Electric Bus) passed all of the relevant tests and was approved in the M3 category [1].

This article considers the special structure of a hybrid electric vehicle with two power sources: a fuel cell and traction batteries. A detailed diagram of the bus drive system is shown in Figure 3.

\section{Bus monitoring using an online platform}

Effective structural optimization in the scope of component selection and costs reduction in the area of the costs of constructing and operating electric-hydrogen buses cannot be based solely on a literature analysis. All the issues, subjected to theoretical analysis, should be validated under real conditions. In order to make this feasible, the bus must have the facilities of a mobile laboratory capable of making advanced measurements of selected parameters. In addition, it must be able to collect large amounts of measurement data and transmit them by various methods of wired and wireless transmission. The next challenge is their processing and 


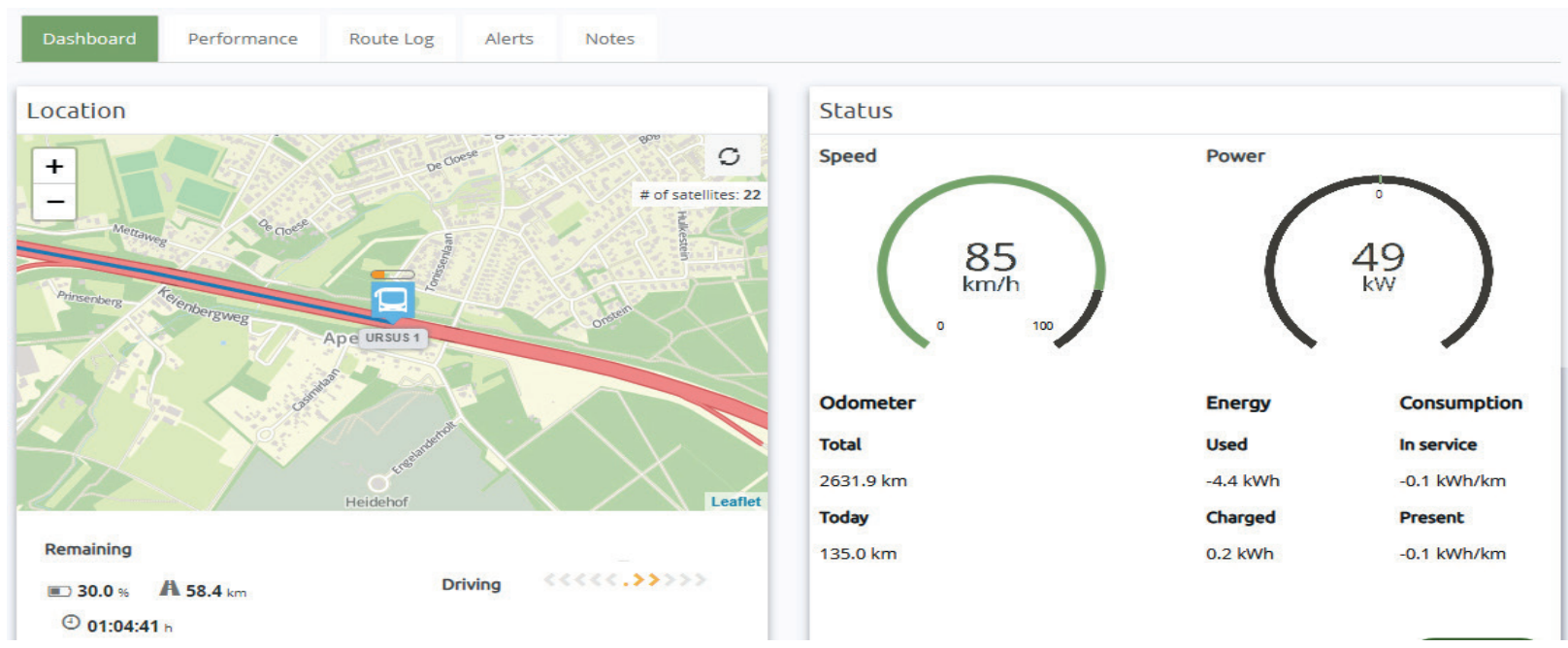

Figure 4 Internet platform window [37]

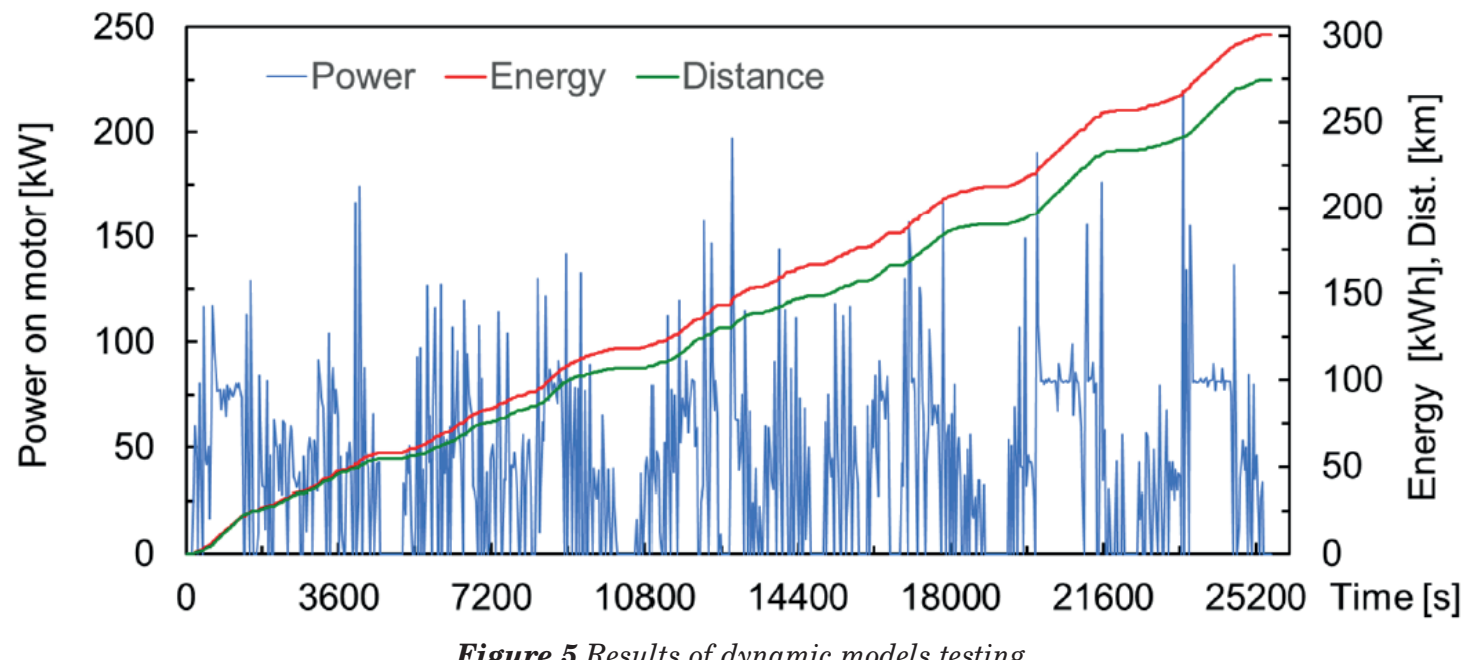

careful analysis. In recent times, advanced systems have been acquired, for transmitting and visualizing data from vehicles. An example is shown in Figure 4.

The platform allows for the on-line reading of selected parameters and their off-line analysis [37]. It is a very useful tool for monitoring the correctness of work, error diagnostics and the optimization of electrichydrogen propulsion systems.

\section{Simulation testing}

Based on the real data from driving an electrichydrogen bus, dynamic models of electricity and hydrogen consumption were constructed on board the bus [38]. The model of the electric-hydrogen drive system takes into account the power of the fuel cell module, its efficiency and the efficiency of the air compressor [39]. Results of testing dynamic models are presented in Figure 5.

After that, a representative inter-city route of $275 \mathrm{~km}$ was chosen, which the vehicle covered at an average speed of $38.6 \mathrm{~km} / \mathrm{h}$ (Figure 6). This distance is too great for a conventional electric bus to travel, especially at such a high speed. Energy of $300 \mathrm{kWh}$ is required to complete the entire journey. It is therefore necessary to use an electric-hydrogen drive. The task of the simulation tests is to determine which components are capable of accumulating electricity (traction batteries) and generating energy (hydrogen fuel cells) on board the vehicle.

Intelligent offline energy management is critical to meeting the requirements of an electric motor, while complying with various restrictions of hybrid vehicles related to system operation, safety conditions and power source designs. Various fuel cell systems and energy split control algorithms [40] have been tested taking into account fuzzy logic/proportional and adaptive [41-42].

Based on simulation tests, the total amount of energy needed to cover a representative route was determined. This energy comes primarily from hydrogen accumulated in the tanks. Only a small part of it comes from the vehicle's traction battery. Based on the exact amounts of hydrogen consumed and the electricity taken to charge the traction batteries, one can calculate the costs of the vehicle's driving along a representative route. 


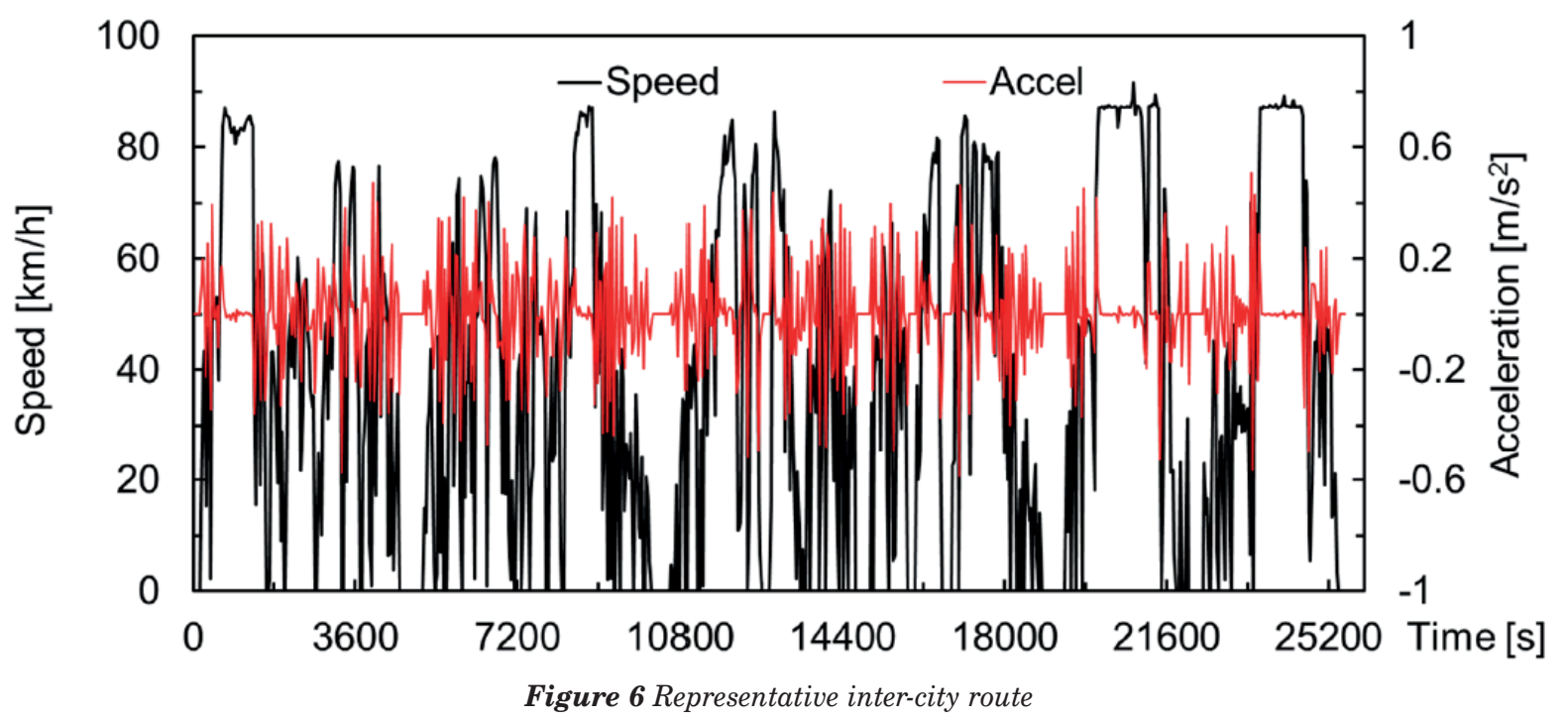

\section{Total costs of ownership calculations}

The main purpose of the research was to determine the total costs of ownership (TCO) resulting from the construction and operation of a hydrogen bus at a given time and with a certain intensity. The costs of building a hydrogen bus were determined based on the component's configuration presented in Section 3. The calculation was made for many variants of sizes of the hydrogen fuel cells and traction batteries. The costs of operating a hydrogen bus on a selected route were calculated based on the simulation tests presented in Section 5. Compared to ICE buses, electric and fuel cell buses have less maintenance costs due to simpler mechanics of its electric motor. Based on the data contained in the report [43], the costs of maintaining a hydrogen bus in European conditions amount to USD $7.02 / 100 \mathrm{~km}$. USD to EUR exchange rate is 0.82 .

The following assumptions were used during the simulation tests:

- the price of a basic bus (called $\mathrm{C}_{\mathrm{BUS}}$ ) with $33 \mathrm{~kg}$ hydrogen tanks is $280,000 €$

- the size of the lithium-ion battery packs is 33.33 $\mathrm{kWh}$ and is scalable to a maximum energy capacity of $233.33 \mathrm{kWh}$

- the power of the hydrogen fuel cell systems is $30 \mathrm{~kW}$ and it is scalable to a maximum power of $210 \mathrm{~kW}$

- the prices of the lithium-ion battery packs (called $\mathrm{C}_{\mathrm{BAT}}$ ) are the average value of 3 offers received from various manufacturers in 2018 and amount to $27,906.98 €$

- the prices of the hydrogen fuel cell systems (called $\mathrm{C}_{\mathrm{FC}}$ ) are the average value of 3 offers received from various manufacturers in 2018 and amount to $58,139.53 €$

- the hydrogen price is $6 € / \mathrm{kg}$

- the price of electricity is $0.2 \mathrm{€} / \mathrm{kWh}$

- the vehicle starts its journey with $100 \%$ charged (SOC) traction batteries
- the traction batteries are not charged from external sources while driving

- the vehicle recovers energy during braking [44]

- no hydrogen refuelling takes place while driving

- the vehicle travels along a representative route 340 days a year over a period of 8 years of operation

- the total costs of ownership include the costs of buying a bus in a given configuration and the costs of fuel (electricity and hydrogen) and costs of maintenance

The bottom-up approach is taken for the TCO analysis across the Europe, across a 8-year timespan. The presented approach takes into account the modular construction of an electric-hydrogen bus from any number of hydrogen fuel cell modules and traction battery packs. This approach looks not only at detailed build costs for a Fuel Cell Bus, down to the drivetrain, fuel system and others, but also at operational costs such as fuel, maintenance and so forth. In authors' opinion this approach is not only unique in the marketplace, but also offers the readers a perspective that can be applied to almost any operational business model.

Equation for calculation of the costs of building a Fuel Cell Bus $\left(\mathrm{TC}_{\mathrm{FCB}}\right)$, in various battery and fuel cell configurations, was determined as:

$\mathrm{TC}_{\mathrm{FCB}}=\mathrm{C}_{\mathrm{BUS}}+\mathrm{C}_{\mathrm{FC}} \times \mathrm{n}_{\mathrm{FC}}+\mathrm{C}_{\mathrm{BAT}} \times \mathrm{n}_{\mathrm{BAT}}$,

where:

$\mathrm{C}_{\mathrm{BUS}}$ - Costs of Basic Bus,

$\mathrm{C}_{\mathrm{FC}}$ - Costs of Fuel Cell Module,

$\mathrm{n}_{\mathrm{FC}}$ - number of Fuel Cell Modules,

$\mathrm{C}_{\mathrm{BAT}}$ - Costs of Battery Pack,

$\mathrm{n}_{\mathrm{BAT}}$ - number of Battery Packs.

As a result of simulation tests the following was determined:

- total costs of building an electric-hydrogen bus in various battery and fuel cell configurations (Table 2) 
Table 2 Costs of the basic bus, battery packs and fuel cell systems in different configurations

\begin{tabular}{|c|c|c|c|c|c|c|c|c|}
\hline \multicolumn{9}{|c|}{ cost of basic bus + battery packs + fuel cell systems $(€)$} \\
\hline & & \multicolumn{7}{|c|}{ fuel cells power $(\mathrm{kW})$} \\
\hline & & 30 & 60 & 90 & 120 & 150 & 180 & 210 \\
\hline \multirow{7}{*}{$\begin{array}{c}\text { battery } \\
\text { capacity } \\
(\mathrm{kWh})\end{array}$} & 33.33 & 366047 & 424186 & 482326 & 540465 & 598605 & 656744 & 714884 \\
\hline & 66.66 & 393953 & 452093 & 510233 & 568372 & 626512 & 684651 & 742791 \\
\hline & 100 & 421860 & 480000 & 538140 & 596279 & 654419 & 712558 & 770698 \\
\hline & 133.33 & 449767 & 507907 & 566047 & 624186 & 682326 & 740465 & 798605 \\
\hline & 166.66 & 477674 & 535814 & 593953 & 652093 & 710233 & 768372 & 826512 \\
\hline & 200 & 505581 & 563721 & 621860 & 680000 & 738140 & 796279 & 854419 \\
\hline & 233.3 & 533488 & 591628 & 649767 & 707907 & 766047 & 824186 & 882326 \\
\hline
\end{tabular}

- the amount of hydrogen (Table 3) and electricity consumed (Table 4)

- fuel costs (electricity + hydrogen)

- TCO (Table 5)

Total costs of building an electric-hydrogen bus in various battery and fuel cell configurations is presented in Table 2. The costs of the electric-hydrogen bus include the costs of the base bus and the number of individual fuel cell modules and traction battery packs. The cheapest version of the base bus with one fuel cell module and one battery pack costs $€ 366,047$. Buses are manufactured in a modular design and any number of fuel cell modules and battery packs can be installed on board. Of course, there are some limitations to the weight of the battery packs and the volume of the fuel cell modules. The greater number of components of the electric-hydrogen drive system reduces the weight and volume of the transported cargo, i.e. passengers. Due to these requirements, the number of fuel cell modules and battery packs is limited to seven. The fuel cell modules are more expensive than battery packs of comparable power. Therefore, a bus with more fuel cell modules than the battery packs will be more expensive.

An important component of the TCO is the costs associated with use of the hydrogen bus. The equation for calculation of the operational costs $\left(\mathrm{C}_{\mathrm{OP}}\right)$ was determined as:

$\mathrm{C}_{\mathrm{OP}}=\mathrm{C}_{\mathrm{H} 2}+\mathrm{C}_{\mathrm{EL}}+\mathrm{C}_{\mathrm{MAINT}}$,

where:

$\mathrm{C}_{\mathrm{H} 2}$ - Hydrogen Costs,

$\mathrm{C}_{\mathrm{EL}}$ - Electricity Costs,

$\mathrm{C}_{\text {MAINT }}$ - Maintenance Costs.

Operating costs of the selected costs items (hydrogen costs, electricity costs, maintenance costs) were set by the following:

- Fuel costs (hydrogen) were calculated based on the specific hydrogen consumption to cover representative route, assumed distance travel $(\Sigma \mathrm{km})$ and actual hydrogen price.

- Electricity costs were calculated based on the specific energy consumption from batteries to cover representative route, assumed travel distance $(\Sigma \mathrm{km})$ and actual electricity price.

- Determination of operating costs also required calculation of other costs. Other costs were defined as a planned repair and maintenance (washing, disinfection, standard repairs), vehicle technical control (1-year intervals) and regular vehicle service control at a mileage of $10000 \mathrm{~km}$. The average costs of maintaining a hydrogen bus in European conditions, as mentioned before, amount to USD $7.02 / 100 \mathrm{~km}$.

The first component of operating costs are the hydrogen costs, which depend on its consumption. Simulations results of the hydrogen consumption necessary to cover a representative route is presented in Table 3. Hydrogen consumption was calculated using the dynamic model described in Section 5. Hydrogen consumption was calculated for each constructional configuration of an electric-hydrogen bus. The calculated hydrogen consumption takes into account the total power and efficiency of the fuel cell modules, as well as the power and efficiency of the air compressor. Buses with smaller number of fuel cell modules will run with a higher load of the fuel cell stacks. Such operating points are characterized by higher efficiency and lower hydrogen consumption. However, they need larger traction battery packs to cover the power requirements of the traction motors.

Due to the consumption of hydrogen, there are certain limitations in the construction of an electrichydrogen bus. Hypothetical cases are highlighted in various colours in Table 3:

- $\quad$ insufficient energy capacity of traction batteries (*)

- battery discharge current too high $\left(^{+}\right.$

- excessive hydrogen consumption $\left(^{\ddagger}\right)$.

For a bus consisting of one fuel cell module and several battery packs, the amount of energy stored and produced in them may not be sufficient to cover the representative route (yellow). For a bus configuration with a small number of battery packs and a large number of fuel cell modules, the hydrogen consumption may be so high that it will not fit into the existing $33 \mathrm{~kg}$ hydrogen tanks. This case is marked in blue. 
Table 3 Hydrogen consumption necessary to cover a representative route

\begin{tabular}{ccccccccc}
\hline \multicolumn{10}{c}{ hydrogen consumption (kg) } \\
\hline \multicolumn{10}{c}{ fuel cells power (kW) } \\
\hline & 30 & 60 & 90 & 120 & 150 & 180 & 210 \\
\hline & 33.33 & $15.94^{*}$ & 28.48 & $35.97^{\ddagger}$ & $38.22^{\ddagger}$ & $44.87^{\ddagger}$ & $56.35^{\ddagger}$ & $70.30^{\ddagger}$ \\
battery & 100 & $12.85^{*}$ & 23.67 & 29.77 & 32.66 & $37.58^{\ddagger}$ & $46.59^{\ddagger}$ & $56.83^{\ddagger}$ \\
capacity & 133.33 & $11.59^{*}$ & 21.44 & 27.55 & 30.09 & $34.23^{\ddagger}$ & $42.15^{\ddagger}$ & $51.01^{\ddagger}$ \\
(kWh) & 166.66 & $10.54^{*}$ & 19.62 & 24.91 & 27.87 & 31.41 & $38.75^{\ddagger}$ & $46.66^{\ddagger}$ \\
& 200 & $8.78^{+}$ & 16.98 & 21.52 & 24.31 & 27.30 & $33.10^{\ddagger}$ & $38.94^{\ddagger}$ \\
& 233.3 & $7.55^{+}$ & 14.88 & 19.08 & 22.11 & 24.75 & 29.84 & $34.67^{\ddagger}$ \\
\hline
\end{tabular}

Table 4 Electricity consumption necessary to cover a representative route

\begin{tabular}{|c|c|c|c|c|c|c|c|c|}
\hline \multicolumn{9}{|c|}{ electrical energy consumption (kWh) } \\
\hline & & 30 & 60 & 90 & 120 & 150 & 180 & 210 \\
\hline \multirow{7}{*}{$\begin{array}{c}\text { battery } \\
\text { capacity } \\
(\mathrm{kWh})\end{array}$} & 33.33 & $109.32^{*}$ & 20.09 & 17.53 & 17.62 & 17.95 & 18.29 & 18.46 \\
\hline & 66.66 & $120.85^{*}$ & 36.27 & 33.97 & 34.07 & 34.39 & 34.77 & 34.95 \\
\hline & 100 & $140.85^{*}$ & 52.72 & 50.46 & 50.57 & 50.87 & 51.27 & 51.45 \\
\hline & 133.33 & $157.09^{*}$ & 69.21 & 66.96 & 67.17 & 67.38 & 67.77 & 67.95 \\
\hline & 166.66 & $170.44^{*}$ & 85.70 & 83.46 & 83.67 & 83.90 & 84.27 & 84.45 \\
\hline & 200 & $192.78^{+}$ & 102.21 & 99.96 & 100.06 & 100.40 & 100.77 & 100.95 \\
\hline & 233.3 & $208.54^{+}$ & 119.23 & 116.46 & 116.67 & 116.91 & 117.27 & 117.44 \\
\hline
\end{tabular}

Table 5 TCOs for different bus configurations

\begin{tabular}{ccccccccc}
\hline \multicolumn{8}{c}{ total costs of ownership (€) } \\
\hline \multicolumn{8}{c}{ fuel cells power (kW) } \\
\hline \multicolumn{10}{c}{30} & 60 & 90 & 120 & 150 & 180 & 210 \\
\hline & 33.33 & $729801^{*}$ & 944077 & $1122983^{\ddagger}$ & $1217998^{\ddagger}$ & $1384831^{\ddagger}$ & $1630458^{\ddagger}$ & $1916388^{\ddagger}$ \\
battery & 66.66 & $740839^{*}$ & 940828 & $1116086^{\ddagger}$ & $1204605^{\ddagger}$ & $1353913^{\ddagger}$ & $1583591^{\ddagger}$ & $1832101^{\ddagger}$ \\
capacity & 100 & $752384^{*}$ & $939119^{\#}$ & 1095585 & 1200895 & $1339551^{\ddagger}$ & $1544983^{\ddagger}$ & $1770323^{\ddagger}$ \\
$(\mathrm{kWh})$ & 133.33 & $768598^{*}$ & 939664 & 1096181 & 1195964 & $1321803^{\ddagger}$ & $1509425^{\ddagger}$ & $1712161^{\ddagger}$ \\
& 166.66 & $786600^{*}$ & 946851 & 1090010 & 1196558 & 1312596 & $1490783^{\ddagger}$ & $1678163^{\ddagger}$ \\
& 200 & $797925^{+}$ & 940535 & 1071580 & 1175415 & 1282384 & $1435422^{\ddagger}$ & $1588955^{\ddagger}$ \\
& 233.3 & $814251^{+}$ & 943438 & 1068667 & 1176345 & 1277693 & 1419073 & $1556167^{\ddagger}$ \\
\hline
\end{tabular}

Simulations results of the electricity consumption, necessary to cover a representative route, is presented in Table 4. The amount of electricity stored in seven lithium-ion battery packs alone is not sufficient to cover the demand for a representative route of $275 \mathrm{~km}$. An electric / hydrogen bus must be equipped with at least one hydrogen fuel cell module. In this case, however, there is another limitation related to the excessive battery discharge current (yellow). The research shows that an electric-hydrogen bus should consist of at least two fuel cell modules and any number of traction battery packs.

The TCO are therefore the sum of the total costs of Fuel Cell Bus $\mathrm{TC}_{\mathrm{FCB}}$ in various battery and fuel cell configurations, Equation (1) and operational costs $\mathrm{C}_{\mathrm{OP}}$, Equation (2) as presented below:
$\mathrm{TCO}=\mathrm{TC}_{\mathrm{FCB}}+\mathrm{C}_{\mathrm{OP}}$

Assumed travel distance $(\Sigma \mathrm{km})$ is based on the length of the representative route $(275 \mathrm{~km})$. The vehicle travels along a representative route 340 days a year over a period of 8 years of operation. The results of the simulation tests of TCO are shown in Table 5.

For the TCO, there is an optimum - minimum (\#) that corresponds to a bus configuration consisting of a $60 \mathrm{~kW}$ fuel cell system and traction batteries with an energy capacity of $100 \mathrm{kWh}$. For a specific representative route, any other configuration of the number of fuel cell modules and lithium ion battery packs will be less economical. Increasing the number of fuel cell modules will only cause them to work with less efficiency, which will contribute to an increase in hydrogen consumption. 
Increasing the number of battery packs will increase the costs of purchasing the bus and increase its weight.

Additional economic and ecological benefits can be obtained by producing electricity and hydrogen from renewable energy sources [45].

\section{Summary and conclusions}

The construction of a structurally and costsoptimized electric-hydrogen bus is not straightforward, but it is feasible. A scientific approach should be used. Firstly. a review of the current state of the relevant science and technology in selected areas is required. These areas are associated with the relevant components needed to construct such a bus. An analysis of the state of the art would enable the selection of the most common and reliable components. This would allow for costs optimization. For the TCO, there is an optimum - minimum that corresponds to a bus configuration consisting of a $60 \mathrm{~kW}$ fuel cell system and traction batteries with an energy capacity of $100 \mathrm{kWh}$. An analysis of the relevant research areas is even more important since it allows for the sourcing of innovative components that will deliver a competitive advantage.

The approach proposed by the authors is universal. It should be carried out at the stage of developing design assumptions for each electric-hydrogen bus. This approach takes into account the purpose of the bus to cover the assumed routes. A different representative route is selected for urban, intercity or mixed travel. Based on that, the basic design assumptions of the electric-hydrogen drive system can be made and the consumption of hydrogen and electricity stored in battery packets can be determined.

Due to the great interest in production of buses powered by hydrogen fuel cells in Poland. the authors plan further research in this area. The dynamic model of the electric-hydrogen drive system can be freely modified as a result of development of components with better performance. Various control algorithms can be used to calculate the energy consumption of the bus needed to travel the representative route. Therefore. the presented approach can be used to make all kinds of comparisons of the system performance and economic costs.

\section{References}

[1] BERGER, R. Fuel cell electric buses - potential for sustainable public transport in Europe. A Study for the fuel cells and hydrogen joint undertaking [online] [accessed 2020-03-13]. 2015. Available from: http://www.fch.europa. eu/sites/default/files/150909_FINAL_Bus_Study_Report_OUT_0.PDF

[2] CHANG, C. C., LIAO, Y. T., CHANG, Y. W. Life cycle assessment of alternative energy types - including hydrogen - for public city buses in Taiwan. International Journal of Hydrogen Energy [online]. 2019, 44(33), p. 18472-18482. ISSN 0360-3199. Available from: https://doi.org/10.1016/j.ijhydene.2019.05.073

[3] LANE, B., SHAFFER, B., SAMUELSEN, G. S. Plug-in fuel cell electric vehicles: a California case study. International Journal of Hydrogen Energy [online]. 2017, 42(20), p. 14294-14300. ISSN 0360-3199. Available from: https://doi.org/10.1016/j.ijhydene.2017.03.035

[4] LEE, D. Y., ELGOWAINY, A., VIJAYAGOPAL, R. Well-to-wheel environmental implications of fuel economy targets for hydrogen fuel cell electric buses in the United States. Energy Policy [online]. 2019, 128, p. 565-583. ISSN 0301-4215. Available from: https://doi.org/10.1016/j.enpol.2019.01.021

[5] GABSAliKHOVA, L., SADYGOVA, G., ALMETOVA, Z. Activities to convert the public transport fleet to electric buses. Transportation Research Procedia [online]. 2018, 36, p. 669-675. ISSN 2352-1465. Available from: https://doi.org/10.1016/j.trpro.2018.12.127

[6] MELO, P., RIBAU, J., SILVA, C. Urban bus fleet conversion to hybrid fuel cell optimal powertrains. Procedia - Social and Behavioral Sciences [online]. 2014, 111, p. 692-701. ISSN 1877-0428. Available from: https://doi.org/10.1016/j.sbspro.2014.01.103

[7] LAIB, F., BRAUN, A., RID, W. Modelling noise reductions using electric buses in urban traffic. a case study from Stuttgart, Germany. Transportation Research Procedia [online]. 2019, 37, p. 377-384. ISSN 2352-1465. Available from: https://doi.org/10.1016/j.trpro.2018.12.206

[8] CORREA, G., MUNOZ, P., FALAGUERRA, T., RODRIGUEZ, C. R. Performance comparison of conventional, hybrid, hydrogen and electric urban buses using well to wheel analysis. Energy [online]. 2017, 141, p. 537-549. ISSN 0360-5442. Available from: https://doi.org/10.1016/j.energy.2017.09.066

[9] FUNEZ GUERRA, C., JAEN CAPARROS, M., NIETO CALDERON, B., SENDARRUBIAS CARBONERO, V., NIETO GALLEGO, E., REYES-BOZO, L., GODOY-FAUNDEZ, A., CLEMENTE-JUL, C., VYHMEISTER, E. Viability analysis of centralized hydrogen generation plant for use in mobility sector. International Journal of Hydrogen Energy [online]. 2018, 43(26), p. 11793-11802. ISSN 0360-3199. Available from: https://doi.org/10.1016/j. ijhydene.2018.04.178

[10] FUNEZ GUERRA, C., REYES-BOZO, L., VYHMEISTER, E., JAEN CAPARROS, M., SALAZAR, J. L., GODOYFAUNDEZ, A., CLEMENTE-JUL, C., VERASTEGUI-RAYO, D. Viability analysis of underground mining 
machinery using green hydrogen as a fuel. International Journal of Hydrogen Energy [online]. 2020, 45(8), p. 5112-5121. ISSN 0360-3199. Available from: https://doi.org/10.1016/j.ijhydene.2019.07.250

[11] NIEOCZYM, A., CABAN, J., DUDZIAK, A., STOMA, M. Autonomous vans - the planning process of transport tasks. Open Engineering [online]. 2020, 10(1), p. 18-25. ISSN 2391-5439. Available from: https://oi.org/10.1515/ eng-2020-0006

[12] NAVAS-ANGUITA, Z., GARCIA-GUSANO, D., DUFOUR, J., IRIBARREN, D. Prospective techno-economic and environmental assessment of a national hydrogen production mix for road transport. Applied Energy [online]. 2020, 259, e114121. ISSN 0306-2619. Available from: https://doi.org/10.1016/j.apenergy.2019.114121

[13] PEI, P., CHEN, D., WU, Z., REN, P. Nonlinear methods for evaluating and online predicting the lifetime of fuel cells. Applied Energy [online]. 2019, 254, e113730. ISSN 0306-2619. Available from: https://doi.org/10.1016/j. apenergy.2019.113730

[14] BIZON, N. Real-time optimization strategies of fuel cell hybrid power systems based on load-following control: a new strategy and a comparative study of topologies and fuel economy obtained. Applied Energy [online]. 2019, 241, p. 444-460. ISSN 0306-2619. Available from: https://doi.org/10.1016/j.apenergy.2019.03.026

[15] DAS, H. S., TAN, C. W., YATIM, A. H. M. Fuel cell hybrid electric vehicles: a review on power conditioning units and topologies. Renewable and Sustainable Energy Reviews [online]. 2017, 76, p. 268-291. ISSN $1364-0321$. Available from: https://doi.org/10.1016/j.rser.2017.03.056

[16] SULAIMAN, N., HANNAN, M. A., MOHAMED, A., MAJLAN, E. H., WANDAUD, W. R. A review on energy management system for fuel cell hybrid electric vehicle: issues and challenges. Renewable and Sustainable Energy Reviews [online]. 2015, 52, p. 802-814. ISSN 1364-0321. Available from: https://doi.org/10.1016/j. rser.2015.07.132

[17] CAUX, S., GAOUA, Y., LOPEZ, P. A combinatorial optimisation approach to energy management strategy for a hybrid fuel cell vehicle. Energy [online]. 2017, 133, p. 219-230. ISSN 0360-5442. Available from: https://doi. org/10.1016/j.energy.2017.05.109

[18] YUAN, J., YANG, L., CHEN, Q. Intelligent energy management strategy based on hierarchical approximate global optimization for plug-in fuel cell hybrid electric vehicles. International Journal of Hydrogen Energy [online]. 2018, 43(16), p. 8063-8078. ISSN 0360-3199. Available from: https://doi.org/10.1016/j.jjhydene.2018.03.033

[19] ZHOU, Y., RAVEY, A., PERA, M. C. Multi-mode predictive energy management for fuel cell hybrid electric vehicles using Markov driving pattern recognizer. Applied Energy [online]. 2020, 258, e114057. ISSN 0306-2619. Available from: https://doi.org/10.1016/j.apenergy.2019.114057

[20] FLETCHER, T., THRING, R., WATKINSON, M. An energy management strategy to concurrently optimise fuel consumption and PEM fuel cell lifetime in a hybrid vehicle. International Journal of Hydrogen Energy [online]. 2016, 41(46), p. 21503-21515. ISSN 0360-3199. Available from: https://doi.org/10.1016/j.ijhydene.2016.08.157

[21] HAMES, Y., KAYA, K., BALTACIOGLU, E., TURKSOY, A. Analysis of the control strategies for fuel saving in the hydrogen fuel cell vehicles. International Journal of Hydrogen Energy [online]. 2018, 43(23), p. 10810-10821. ISSN 0360-3199. Available from: https://doi.org/10.1016/j.ijhydene.2017.12.150

[22] ZHANG, H., LI, X., LIU, X., YAN, J. Enhancing fuel cell durability for fuel cell plug-in hybrid electric vehicles through strategic power management. Applied Energy [online]. 2019, 241, p. 483-490. ISSN 0306-2619. Available from: https://doi.org/10.1016/j.apenergy.2019.02.040

[23] CIPOLLONE, R., DI BATTISTA, D., MARCHIONNI, M., VILLANTE, C. Model based design and optimization of a fuel cell electric vehicle. Energy Procedia [online]. 2014, 45, p. 71-80. ISSN 1876-6102. Available from: https://doi.org/10.1016/j.egypro.2014.01.009

[24] DE MIRANDA, P. E. V., CARREIRA, E. S., ICARDI, U. A., NUNES, G. S. Brazilian hybrid electric-hydrogen fuel cell bus: improved on-board energy management system. International Journal of Hydrogen Energy [online]. 2017, 42(19), p. 13949-13959. ISSN 0360-3199. Available from: https://doi.org/10.1016/j.ijhydene.2016.12.155

[25] BIZON, N. Efficient fuel economy strategies for the fuel cell hybrid power systems under variable renewable/load power profile. Applied Energy [online]. 2019, 251, e113400. ISSN 0306-2619. Available from: https://doi.org/10.1016/j.apenergy.2019.113400

[26]ZA wheel - energy savings lifeline - Ziehl-Abegg [online] [accessed 2020-03-13]. 2015. Available from: https://www.ziehl-abegg.com/gb/en/downloads/file/get/10917/

[27] JWA, K., LIM, O. Comparative life cycle assessment of lithium-ion battery electric bus and Diesel bus from well to wheel. Energy Procedia [online]. 2018, 145, p. 223-227. ISSN 1876-6102. Available from: https://doi. org/10.1016/j.egypro.2018.04.039

[28] WANG, L., WANG, Z., JU, Q. Characteristic analysis of lithium titanate battery. Energy Procedia [online]. 2017, 105, p. 4444-4449. ISSN 1876-6102. Available from: https://doi.org/10.1016/j.egypro.2017.03.942

[29] TONG, H. Y. Development of a driving cycle for a supercapacitor electric bus route in Hong Kong. Sustainable Cities and Society [online]. 2019, 48, e101588. ISSN 2210-6707. Available from: https://doi.org/10.1016/j. scs.2019.101588 
[30] ODEIM, F., ROES, J., HEINZEL, A. Power management optimization of an experimental fuel cell/battery/ supercapacitor hybrid system. Energies [online]. 2015, 8, p. 6302-6327. eISSN 1996-1073. Available from: https://doi.org/10.3390/en8076302

[31] XYLIA, M., SILVEIRA, S. The role of charging technologies in upscaling the use of electric buses in public transport: experiences from demonstration projects. Transportation Research Part A: Policy and Practice [online]. 2018, 118, 399-415. ISSN 0965-8564. Available from: https://doi.org/10.1016/j.tra.2018.09.011

[32] ZULIANI, N., TACCANI, R. Micro-cogeneration system based on HTPEM fuel cell fuelled with natural gas: performance analysis. Applied Energy [online]. 2012, 97, p. 802-808. ISSN 0306-2619. Available from: https://doi.org/10.1016/j.apenergy.2011.12.089

[33] AHLUWALIA, R. K., PENG, J., ROH, H. S., HUA, T. Q., JAMES, B. D. Supercritical cryo-compressed hydrogen storage for fuel cell electric buses. International Journal of Hydrogen Energy [online]. 2018, 43(22), p. 1021510231. ISSN 0360-3199. Available from: https://doi.org/10.1016/j.ijhydene.2018.04.113

[34] FAZLE KIBRIAA, A. K. M., MOA, Y. H., PARKA, K. S., NAHMA, K. S., YUN, M. H. Electrochemical hydrogen storage behaviors of $\mathrm{CVD}, \mathrm{AD}$ and $\mathrm{LA}$ grown carbon nanotubes in $\mathrm{KOH}$ medium. International Journal of Hydrogen Energy [online]. 2001, 26(8), p. 823-829. ISSN 0360-3199. Available from: https://doi.org/10.1016/S03603199(01)00007-6

[35] GENG, C., JIN, X., ZHANG, X. Simulation research on a novel control strategy for fuel cell extended-range vehicles. International Journal of Hydrogen Energy [online]. 2019, 44(1), p. 408-420. ISSN 0360-3199. Available from: https://doi.org/10.1016/j.ijhydene.2018.04.038

[36] ALVAREZ FERNANDEZA, R., CORBERA CARABALLO, S., BELTRAN CILLERUELO, F., LOZANO, J. A. Fuel optimization strategy for hydrogen fuel cell range extender vehicles applying genetic algorithms. Renewable and Sustainable Energy Reviews [online]. 2018, 81(1), p. 655-668. ISSN 1364-0321. Available from: http://dx.doi. org/10.1016/j.rser.2017.08.047

[37] Viriciti Internet Platform [online] [accessed 2020-03-30]. Available from: https://dashboard.viriciti.com

[38] VEPSALAINEN, J., OTTO, K., LAJUNEN, A., TAMMI, K. Computationally efficient model for energy demand prediction of electric city bus in varying operating conditions. Energy [online]. 2019, 169, p. 433-443. ISSN 03605442. Available from: https://doi.org/10.1016/j.energy.2018.12.064

[39] HUNICZ, J., KASPEREK, D., MALEK, A., SMIETANKA, M. Real-time monitoring and energy split optimization of a hybrid fuel-cell-battery city bus. In: 2nd International Conference on Science and Technology Research ICSTR: proceedings. 2019.

[40] CAI, Y., OUYANG, M. G., YANG, F. Impact of power split configurations on fuel consumption and battery degradation in plug-in hybrid electric city buses. Applied Energy [online]. 2017, 188, p. 257-269. ISSN 0306-2619. Available from: https://doi.org/10.1016/j.apenergy.2016.11.126

[41] ZHANG, S., HU, X., XIE, S., SONG, Z., HOU, C. Adaptively coordinated optimization of battery aging and energy management in plug-in hybrid electric buses. Applied Energy [online]. 2019, 256, e113891. ISSN 0306-2619. Available from: https://doi.org/10.1016/j.apenergy.2019.113891

[42] ETTIHIR, K., HIGUITA CANO, M., BOULON, L., AGBOSSOU, K. Design of an adaptive EMS for fuel cell vehicles. International Journal of Hydrogen Energy [online]. 2017, 42(2), p. 1481-1489. ISSN 0360-3199. Available from: https://doi.org/10.1016/j.ijhydene.2016.07.211

[43] Fuelling the future of mobility hydrogen and fuel cell solutions for transportation - Deloitte Financial Advisory, Deloitte, China [online]. 2020. Available from: https:/www2.deloitte.com/content/dam/Deloitte/cn/Documents/ finance/deloitte-cn-fueling-the-future-of-mobility-en-200101.pdf

[44] CABAN, J., ZARAJCZYK, J., MALEK, A. Possibilities of using electric drives in city buses. In: 23rd International Scientific Conference Transport Means: proceedings. 2019. p. 543-547.

[45] MALEK, A., CABAN, J., WOJCIECHOWSKI, L. Charging electric cars as a way to increase the use of energy produced from RES. Open Engineering [online]. 2020, 10(1), p. 98-104. ISSN 2391-5439. Available from: https://doi.org/10.1515/eng-2020-0009 